\title{
Applications of Coumarins as Cardiovascular and Anti-Cancer Agents: A Short Review
}

\author{
Tejas Padte, Suhas Pednekar and Pushkar Shejwalkar* \\ Ramnarain Ruia Autonomous College, India
}

Submission: December 04, 2017; Published: December 20, 2017

*Corresponding author: Pushkar Shejwalkar, Ramnarain Ruia Autonomous College, L.N. Road, Matunga, India,

Email: pshejwalkar2004@gmail.com

\begin{abstract}
Coumarins (2H-1-benzopyran-2-one), an important class of heterocyclic compounds, and its derivatives can be found in many natural or synthetic drug molecules and possess versatile bioactivities making them important molecules for medical practitioners and medicinal chemists. Coumarins have found applications in drug molecules especially related to oncogenic and cardiovascular dysfunctions. Cardiovascular diseases and cancer are lifestyle diseases that have become plague to the society. This review highlights the bioactivities of Coumarins towards these life threatening diseases.
\end{abstract}

Keywords: Coumarins; Anti-cancer; Cardio-vascular; Anti-coagulant; Anti-oxidant

\section{Introduction}

Coumarins (1), are naturally occurring fragrant compounds belonging to the benzopyrone family and have been used in perfumes since 1882 [1]. Coumarins have also attracted the interest of biochemists and medicinal chemists for a long time due to their diverse biological activities [2]. Over and above the discoveries made by isolation of Coumarins from the hundreds of species of plants and other organisms, synthetic analogues have availed numerous and varied Coumarins. These natural as well as synthetic derivatives of Coumarins have drawn much attention due to their diverse pharmacological activities [3]. Various moieties when combined with Coumarins can produce same or different effects with different potencies.

Many Coumarins and their synthetic derivatives thus exist and exhibit anti-coagulant, anti-tumor, anti-viral, anti-inflammatory, anti-oxidant, anti-microbial and enzyme inhibitory properties [2,4-7] (Figure 1).

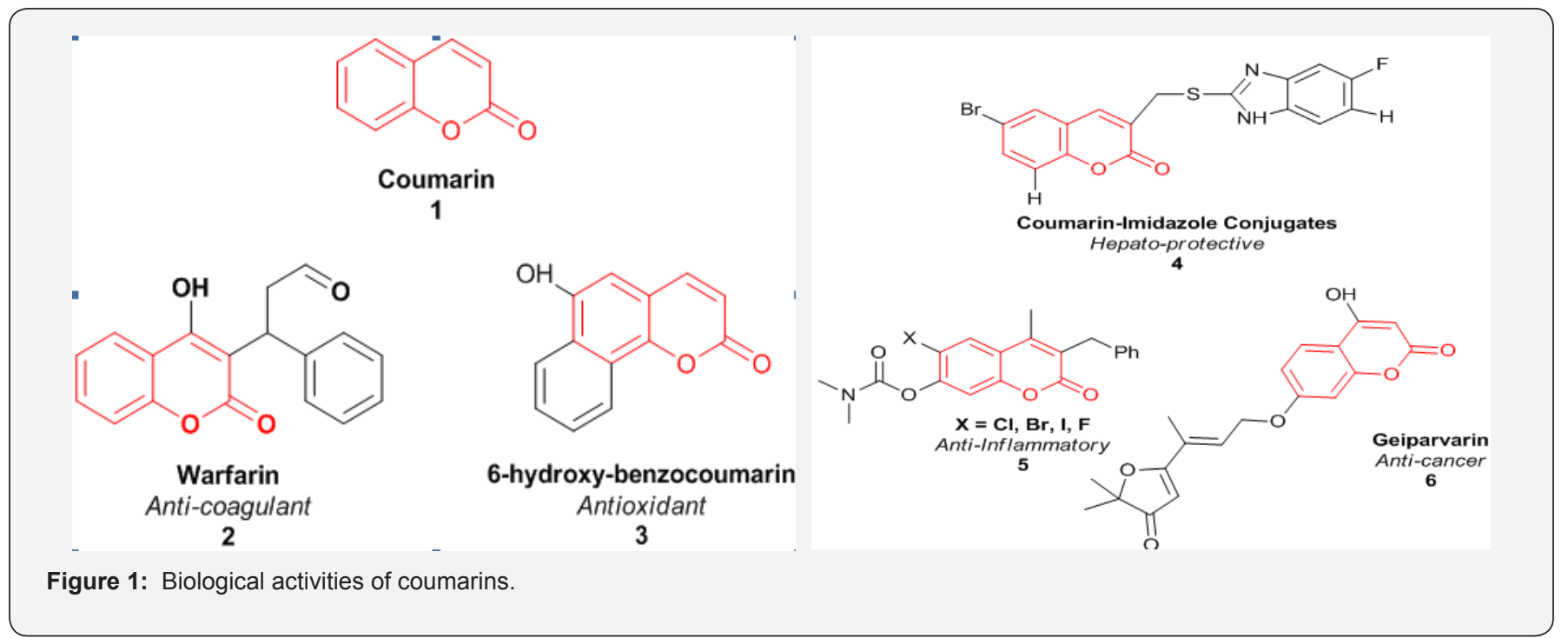


Coumarins are naturally occurring anticoagulants. They act as a competitive inhibitor of vitamin K epoxide reductase, an enzyme that recycles vitamin $\mathrm{K}$. Vitamin K epoxide reductase (VKOR) is an integral membrane protein that catalyzes the reduction of vitamin $\mathrm{K}$ 2,3-epoxide and vitamin $\mathrm{K}$ to vitamin $\mathrm{K}$ hydroquinone, a cofactor required for the gamma-glutamyl carboxylation reaction (Figure 2). The VKOR decreases the concentration of reduced vitamin
$\mathrm{K}$, which reduces the rate of vitamin K-dependent carboxylation and leads to under-carboxylated, inactive vitamin K-dependent proteins. It is proposed that an active site disulfide needs to be reduced for the enzyme to be active. VKOR uses two sulfhydryl groups for the catalytic reaction and these two sulfhydryl groups are oxidized back to a disulfide bond during each catalytic cycle [8-10].

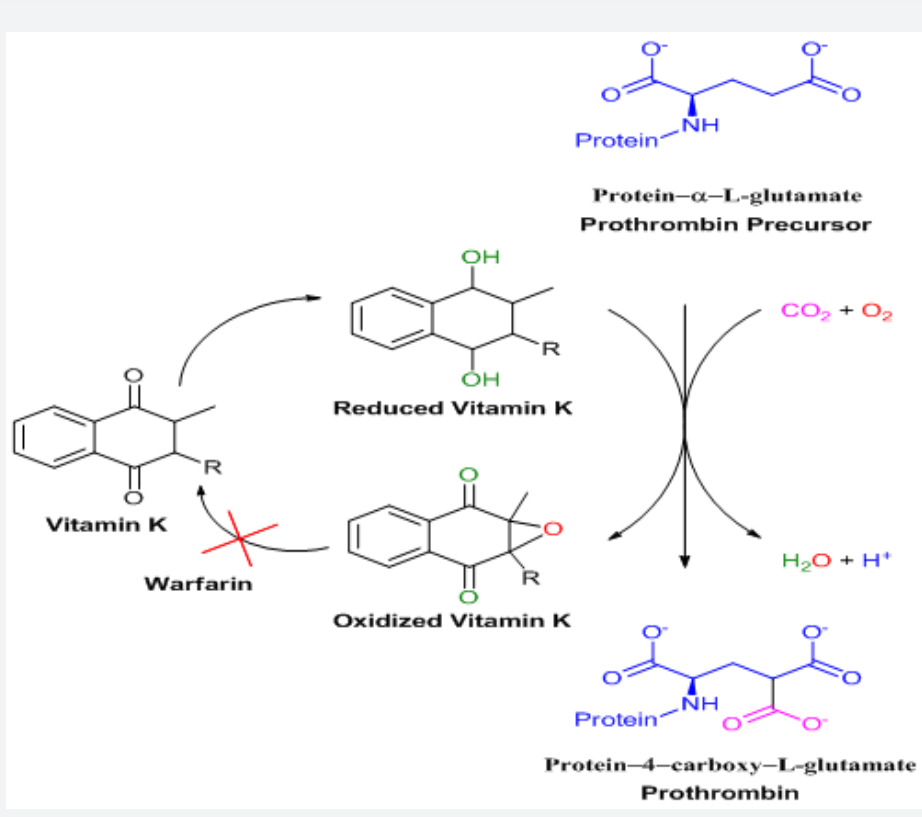

Figure 2: Mechanism of action.

\section{Cardiovascular Agents}

Coumarin based anticoagulants are effective in the treatment and prevention of arterial and venous thrombosis. Nowadays, the main clinical use of coumarins based anticoagulants is the prevention of stroke or systemic embolism in patients with arterial fibrillation, which is one of the most common cardiac disorders $[8,11]$.

Coumarins are also known to possess anti-oxidant property, which attributes to direct scavenging of reactive oxygen and nitrogen species (ROS and RONs). One important mechanism through which this is achieved is by donating hydrogen to free radicals in its reduction to nonreactive species. Addition of hydrogen would remove the odd electron feature that is responsible for radical reactivity [12]. It is also observed due to inhibition of enzymes like xanthene oxidase, which are responsible for formation of these free radicals $[13,14]$. Coumarins thus also exhibit positive cardiovascular effects partially due to their antioxidant activity. Many coumarins have been shown to relax the contractions of vascular smooth muscle induced by mediators like sympathomimetics nor epinephrine and phenylephrine or high doses of potassium chloride (KCl) [11]. Methoxy derivative of Osthole extracted from Cnidium monnieri (C. monnieri) exhibited vasodilatory effect on rabbit corpus cavernosum. Similar activity was observed for some butyrolactone derived Coumarins [15].
The basic mechanism for vascular relaxations is by controlling the intracellular concentration of calcium ions. Coumarins are proposed to block the entry of calcium ion by inhibiting its release from the sarcoplasmic reticulum or stop the in-flow of calcium through voltage dependent calcium channels and receptoroperated calcium channels located in the membrane of smooth muscle cells [11].

\section{Anti-Cancer Agents}

Coumarin and its derivatives have also been used for treatment of variety of cancer. Coumarin derivatives when used in conjunction with other modes of treatment may provide better results [16]. The current work also attempts to highlight the cytotoxic activities of coumarins on different types of cancers (Figure 3).

\section{Breast Cancer}

Coumarin derivatives, 7-hydroxycoumarin 7, and its substituted analogues have shown to decrease cell proliferation in case of breast cancer [17]. 5,6-benzo-[ $\alpha]$-pyrone, or 1,2-benzopyrone substituted derivatives have shown to decrease the lymphedema through stimulation of proteolysis by tissue macrophages [18]. It has been observed that substitution at C-3 position via an amide linkage has shown promising activity against melanoma and breast cancer cell lines [19]. A family of coumarin-3-(N-aryl) carboxamides (8) (Figure 3) were prepared 
and evaluated as cytotoxic agents against SKBr3 and BT474 breast cancer cell lines as well as normal HFLs (human lung fibroblasts that do not over express the ErbB-2 and EGFR). The SAR (structure activity relationship) studies showed that the substitutions on the Coumarin ring and also on the N-phenyl moiety can strongly affect the cytotoxic profile of the compounds [20].

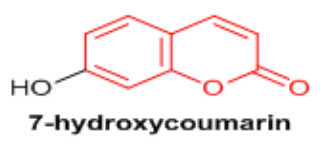

7<smiles>[Y]c1cccc(NC(=O)c2cc3ccccc3oc2=O)c1</smiles>

8

$$
\text { coumarin-3-(N-aryl)carboxamides }
$$<smiles>[R4]N[Y]NC(=O)/C(=C/c1ccccc1[X])C([X])=O</smiles><smiles>CC(C)=NNC(=O)c1cc2ccccc2oc1=O</smiles>

11

Hydrazide and Hydrazone derivatives of Coumarins

Figure 3: Coumarin-3-derivatives with anti-cancer activity.

Series of Coumarin and quinolinone-3-carboxamide derivatives 9 and 10 (Figure 3) were synthesized and examined for their anticancer activities against several cancer cell lines including prostate cancer cells DU145 and PC3, colon cancer HCT15, breast cancer MCF7, ovarian cancer IGROV1, liver cancer SKHep1, and leukemia cancer HL60(TB). The above study by Matiadis et al. [21] demonstrated that Coumarin derivative containing $\mathrm{N}$-(8-aminooctyl) side chain $[\mathrm{X}=\mathrm{O}, \mathrm{Y}=(\mathrm{CH} 2) 8$, and $\mathrm{R}=\mathrm{H}]$ had the highest inhibitory effects against DU145 prostate cancer cells $(\mathrm{GI} 50<10 \mathrm{mM})$. Mohareb et al. [22] synthesized several hydrazide hydrazone derivatives including coumarin 11,12 (Figure 4). The study conducted by Mohareb et al. [22] showed that effect of 11, on the in vitro growth of three human tumor cell lines namely breast adenocarcinoma (MCF7), non-small cell lung cancer (NCIH460) and CNS cancer (SF268) indicated that the best inhibitory activity was against NCIH460 with IC50 value of $10 \mathrm{mM}$ [22].

\section{Lung Cancer}

Coumarin and 7-hydroxycoumarin inhibited cell growth by inducing cell cycle arrest in the G1 phase in all the lung carcinoma cell lines [23]. Series of dicoumarol derivatives 13 and their condensation products with acetic anhydride 14 (Figure 4) have shown promising activity against SK-LU-1, SPC-A-1 and 95D human lung cancer cell lines [24]. Amino side chains or alkoxy derivatives of coumarins have shown to induce apoptosis in the human lung (A549) cancer cell line [25].<smiles>[R]C(c1c(O)c2ccccc2oc1=O)c1c(O)c2ccccc2oc1=O</smiles>

13<smiles>[R2]C1c2c(c3ccccc3oc2=O)Oc2c1c(=O)oc1ccccc21</smiles>

14
Figure 4: Dicoumarols and their condensation derivatives.

Anti-Leukemic Activity

5-methoxy-6,7-methylenedioxy coumarin and 5-(3-methyl2-butenyloxy)- or 6,7-methylenedioxy coumarin inhibited proliferation and induced differentiation in human leukemia U-937 cells [26]. The Complexes of cerium(III), lanthanum(III) and neodymium(III) with 4-methyl-7-hydroxy coumarin showed marginal cytotoxic activity against transformed leukemic cell lines (P3HR1 and THP-1) as compared to the inorganic salts [27].

\section{Pancreatic Cancer}

A series of isoprenylated Coumarins 15 and 16 (Figure 5) were designed, synthesized, and evaluated against human pancreatic adenocarcinoma cell line PANC-1 yielding a series of potent and selective cytotoxic agents under nutrient deprived conditions [28]. 
<smiles>CC(C)=CCC/C(C)=C/CC/C(C)=C/CC/C(C)=C/COc1ccc2ccc(=O)oc2c1</smiles>

15

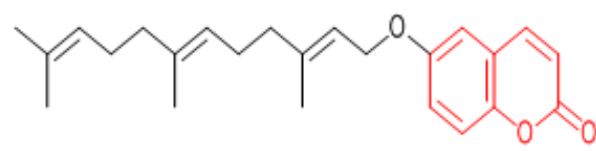

16

Figure 5: Isoprenylated derivatives of Coumarins.

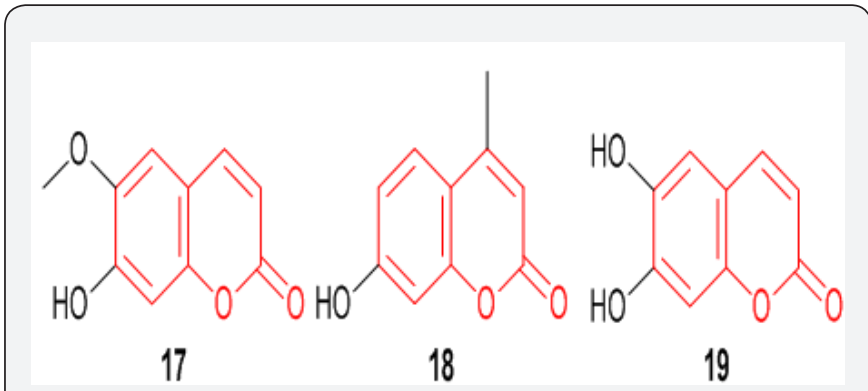

Figure 6: Coumarin based analogues against skin cancers.

Coumarins and their substituted analogues have also proven themselves as potential candidates to treat skin cancer. Scopoletin 17 an alkaloid separated from ethanolic extract of the medicinal plant, Gelsemium sempervirens (Fam: Loganiaceae) has been reported to have anti-cancer potential [29] (Figure 6) Bhattacharya et al. [30] reported that 4-methyl-7-hydroxycoumarin 18 compound has a great potential as a possible anti-cancer drug, particularly in polycyclic aromatic hydrocarbon induced skin cancer [30]. Jeon \& Young-Joo et al. [31] demonstrated that esculetin 19 induced apoptosis in the HMM cells by down regulating $\mathrm{Sp} 1$ protein levels. Their results suggest that esculetin may be a potential anti-proliferative agent that induces apoptotic cell death in G361 HMM cells [31].

\section{Cervical Cancer}

Cervical cancers are one of the most common gender-specific cancers affecting women worldwide. The effects of coumarin on cell viability, cell cycle arrest and induction of apoptosis were investigated in human cervical cancer HeLa cells by Chuang \& Jing-Yuan et al. [32]. It was observed that coumarin was cytotoxic with an IC50 of 54.2microM, induced morphological changes, and caused G0/G1 arrest and apoptosis.

\section{Miscellaneous}

The antitumor activity of a novel coumarin derivatives 5,7-dihydroxy-4-methyl-6-(3-methylbutanoyl)-Coumarin (DMAC) 20, on colorectal carcinoma was investigated. DMAC was initially investigated due to its structural similarity to the cytostatic agent ochrocarpin B 21 (Figure 7). Ochrocarpin B was extracted from the bark of Ochrocarpos punctatus, along

with several other coumarins and benzophenone derivatives, all exhibiting cytotoxicity against an ovarian cancer cell line [33]. Indeed, a large number of synthetic and natural Coumarins act as cytotoxic agents [34]. Treatment of colon cancer HCT116 and LoVo cells with DMAC resulted in substantial proapoptotic activity. The combination of DMAC 38 treatment with the established anticancer drugs 5-FU and CPT-11 enhanced their therapeutic efficacies. Structure activity studies on DMAC related compounds led to the conclusion that substitution at 6-position is crucial for inducing cell apoptosis and a phenyl group at 4-position presumably enhances the bioactivity [35]. New cytostatic agents based on the DMAC structure could therefore lead to interesting new therapeutic valuable compounds.<smiles>Cc1cc(=O)oc2cc(O)c(C(=O)CC(C)C)c(O)c12</smiles>

20

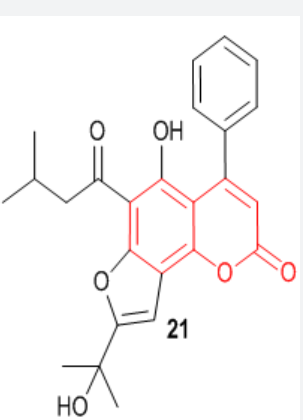

Figure 7: DMAC and Ochrocarpin-Structural Similarity.

\section{Conclusion}

The life altering events like cardiovascular diseases or cancer are a plague to society and affect many families across the globe. This review highlights the versatility of coumarins molecules and their multiple biological activities, thus highlighting their importance and tremendous scope for future medical practitioners and medicinal chemists.

\section{References}

1. Khan SA, Khan SB, Asiri AM, Ahmad I (2016) Zirconia-based catalyst for the one-pot synthesis of coumarin through Pechmann reaction. Nanoscale Res Lett 11(1): 345

2. Borges F, Roleira F, Milhazes N, Santana L, Uriarte E, et al. (2005) Simple coumarins and analogues in medicinal chemistry: occurrence, synthesis and biological activity. Curr Med Chem 12(8): 887-916.

3. Kapdi AR, Jain C, Padte T, Shevde U, Pednekar S, et al. (2013) Tween-80: a bio-degradable and recyclable phase transfer catalyst for microwave assisted synthesis of highly substituted dicoumarols. International Journal of Green Chemistry and Bioprocess 3(2): 17-23.

4. Riveiro ME, De Kimpe N, Moglioni A, Vázquez R, Monczor F, et al. (2010) Coumarins: old compounds with novel promising therapeutic perspectives. Curr Med Chem 17(13): 1325-1338.

5. Cheng JF, Chen M, Wallace D, Tith S, Arrhenius T, et al. (2004) Discovery and structure-activity relationship of coumarin derivatives as TNF- $\alpha$ inhibitors. Bioorg Med Chem Lett 14(10): 2411-2415.

6. Hwu JR, Singha R, Hong SC, Chang YH, Das AR, et al. (2008) Synthesis of new benzimidazole-coumarin conjugates as anti-hepatitis $C$ virus agents. Antiviral Res 77(2): 157-162.

7. Atmaca M, Bilgin HM, Obay BD, Diken H, Kelle M, et al. (2011) The hepatoprotective effect of coumarin and coumarin derivates on carbon 
tetrachloride-induced hepatic injury by antioxidative activities in rats. J Physiol Biochem 67(4): 569-576.

8. Schulman S, Svenungsson E, Granqvist S (1998) Anticardiolipin antibodies predict early recurrence of thromboembolism and death among patients with venous thromboembolism following anticoagulant therapy. Am J Med 104(4): 332-338.

9. Ren P, Stark PY, Johnson RL, Bell RG (1977) Mechanism of action of anticoagulants: correlation between the inhibition of prothrombin synthesis and the regeneration of vitamin K1 from vitamin K1 epoxide. J Pharmacol Exp Ther 201(3): 541-546.

10. Tie JK, Stafford DW (2008) Structure and function of vitamin K epoxide reductase. Vitam Horm 78: 103-130.

11. Najmanová I, Doseděl M, Hrdina R, Anzenbacher P, Filipský T, et al. (2015) Cardiovascular effects of coumarins besides their antioxidant activity. Curr Top Med Chem 15(9): 830-849.

12. Al-Amiery AA, Al-Majedy YK, Kadhum AA, Mohamad AB (2015) Novel macromolecules derived from coumarin: synthesis and antioxidant activity. Sci Rep 5: 11825 .

13. Bubols GB, Vianna Dda R, Medina-Remon A, von Poser G, Lamuela-Raventos RM, et al. (2013) The antioxidant activity of coumarins and flavonoids. Mini Rev Med Chem 13: 318-334.

14. Vianna DR, Bubols G, Meirelles G, Silva BV, da Rocha A, et al. (2012) Evaluation of the antioxidant capacity of synthesized coumarins. Int J Mol Sci 13(6): 7260-7270.

15. Rahman A, Choudhary MI, Reitz AB (2010) Frontiers in medicinal chemistry. United Arab Emirates, Vol 4.

16. Rehman S, Ikram M, Khan A, Min S, Azad E, et al. (2013) New dicoumarol sodium compound: crystal structure, theoretical study and tumoricidal activity against osteoblast cancer cells. Chem Cent J 7: 110.

17. Musa MA, Cooperwood JS, Khan MOF (2008) A review of coumarin derivatives in pharmacotherapy of breast cancer. Curr Med Chem 15(26): 2664-2679.

18. Loprinzi CL, Kugler JW, Sloan JA, Rooke TW, Quella SK, et al. (1999) Lack of effect of coumarin in women with lymphedema after treatment for breast cancer. N Engl J Med 340(5): 346-350.

19. Emami S, Dadashpour S (2015) Current developments of coumarin-based anti-cancer agents in medicinal chemistry. Eur J Med Chem 102: 611-630.

20. Reddy NS, Gumireddy K, Mallireddigari MR, Cosenza SC, Venkatapuram $\mathrm{P}$, et al. (2005) Novel coumarin-3-(N-aryl)carboxamides arrest breast cancer cell growth by inhibiting ErbB-2 and ERK1. Bioorg Med Chem 13(9): 3141-3147.

21. Matiadis D, Stefanou V, Athanasellis G, Hamilakis S, McKee V, et al. (2013) Synthesis, X-ray crystallographic study, and biological evaluation of coumarin and quinolinone carboxamides as anticancer agents. Monatshefte Für Chemie-Chemical Monthly 144(7): 1063-1069.

22. Mohareb RM, Fleita DH, Sakka OK (2010) Novel synthesis of hydrazide-hydrazone derivatives and their utilization in the synthesis of coumarin, pyridine, thiazole and thiophene derivatives with antitumor activity. Molecules 16(1): 16-27.

23. Lopez-Gonzalez JS, Prado-Garcia H, Aguilar-Cazares D, Molina-Guarneros JA, Morales-Fuentes J, et al. (2004) Apoptosis and cell cycle disturbances induced by coumarin and 7-hydroxycoumarin on human lung carcinoma cell lines. Lung Cancer 43(3): 275-283.

24. Weng KG, Yuan YL (2017) Synthesis and evaluation of coumarin derivatives against human lung cancer cell lines. Braz J Med Biol Res 50(11): e6455.

25. Musa MA, Badisa VL, Latinwo LM, Patterson TA, Owens MA (2012) Coumarin-based Benzopyranone Derivatives Induced Apoptosis in Human Lung (A549) Cancer Cells. Anticancer Res 32(10): 4271-4276.

26. Riveiro ME, Maes D, Vázquez R, Vermeulen M, Mangelinckx S, et al. (2009) Towards establishing structure-activity relationships for oxygenated coumarins as differentiation inducers of promonocytic leukemic cells. Bioorg Med Chem 17(18): 6547-6559.

27. Kostova I, Manolov I, Nicolova I, Konstantinov S, Karaivanova M, et al. (2001) New lanthanide complexes of 4-methyl-7-hydroxycoumarin and their pharmacological activity. Eur J Med Chem 36(4): 339-347.

28. Jun M, Bacay AF, Moyer J, Webb A, Carrico-Moniz D, et al. (2014) Synthesis and biological evaluation of isoprenylated coumarins as potential anti-pancreatic cancer agents. Bioorg Med Chem Lett 24(19): 4654-4658.

29. Zhao P, Chen L, Li LH, Wei ZF, Tong B, et al. (2014) SC-III3, a novel scopoletin derivative, induces cytotoxicity in hepatocellular cancer cells through oxidative DNA damage and ataxia telangiectasia-mutated nuclear protein kinase activation. BMC Cancer 14: 987.

30. Bhattacharyya SS, Paul S, Mandal SK, Banerjee A, Boujedaini N, et al. (2009) A synthetic coumarin (4-Methyl-7 hydroxy coumarin) has anti-cancer potentials against DMBA-induced skin cancer in mice. Eur J Pharmacol 614(1-3): 128-136.

31. Jeon YJ, Jang JY, Shim JH, Myung PK, Chae JI, et al. (2015) Esculetin, a coumarin derivative, exhibits anti-proliferative and pro-apoptotic activity in G361 human malignant melanoma. J Cancer Prev 20(2): 106112.

32. Chuang JY, Huang YF, Lu HF, Ho HC, Yang JS, et al. (2007) Coumarin induces cell cycle arrest and apoptosis in human cervical cancer HeLa cells through a mitochondria and caspase- 3 dependent mechanism and NF-kappaB down-regulation. In vivo 21(6): 1003-1009.

33. Chaturvedula VS, Schilling JK, Kingston DG (2002) New cytotoxic coumarins and prenylated benzophenone derivatives from the bark of ochrocarpos punctatus from the Madagascar rainforest. J Nat Prod 65(7): 965-972.

34. Kostova I (2005) Synthetic and natural coumarins as cytotoxic agents. Curr Med Chem AntiCancer Agents 5(1): 29-46.

35. Lin MH, Cheng CH, Chen KC, Lee WT, Wang YF, et al. (2014) Induction of ROS-independent JNK-activation-mediated apoptosis by a novel coumarin-derivative, DMAC, in human colon cancer cells. Chem Biol Interact 218: 42-49. 
(CC) This work is licensed under Creative

BY DOI: $10.19080 /$ JOCCT.2017.08.555749
Your next submission with Juniper Publishers will reach you the below assets

- Quality Editorial service

- Swift Peer Review

- Reprints availability

- E-prints Service

- Manuscript Podcast for convenient understanding

- Global attainment for your research

- Manuscript accessibility in different formats

( Pdf, E-pub, Full Text, Audio)

- Unceasing customer service

Track the below URL for one-step submission https://juniperpublishers.com/online-submission.php 